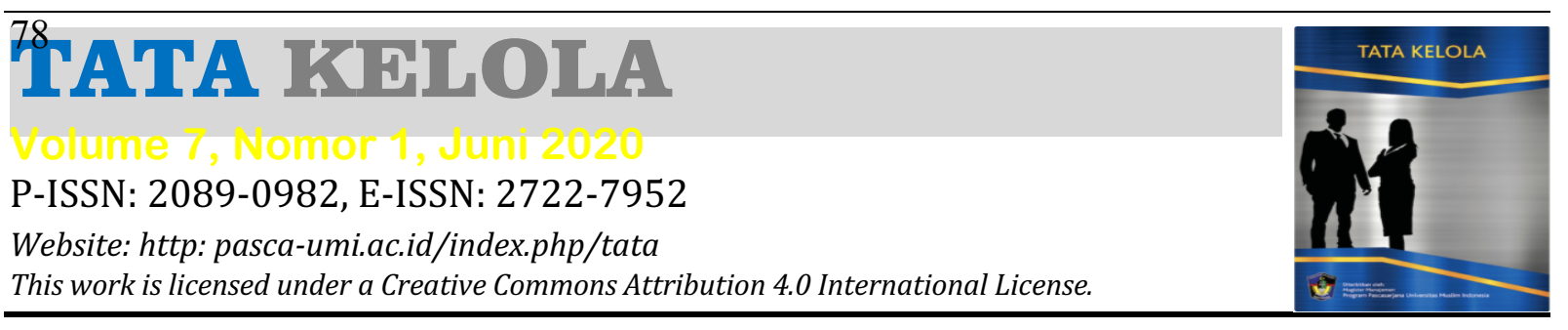

\title{
Pengaruh Bauran Pemasaran Terhadap Kepuasan Pelanggan Trans Studio Makassar
}

\author{
Mira Hijriah', Mahfud Nurnajamuddin², Serlin Serang ${ }^{3}$ \\ 12,3, Magister Manajemen, Universitas Muslim Indonesia. \\ ${ }^{1}$ Koresponden Penulis, E-mail:mira.hijriah@gmail.com
}

\begin{abstract}
ABSTRAK
Tujuan penelitian ini adalah untuk menganalisis Pengaruh Bauran Pemasaran Terhadap Kepuasan Pengunjung Pada Trans Studio Makassar. Pendekatan penelitian yang digunakan adalah pendekatan deskriptif dan eksplanatori dengan metode kuantitatif dan kualitatif. Metode penelitian yang digunakan adalah regresi berganda dengan bantuan program SPSS V. 16, untuk sampel dalam penelitian ini adalah 116 orang pelanggan. Hasil penelitian menunjukkan bahwa: Harga berpengaruh positif dan signifikan terhadap kepuasan pelanggan Trans Studio Makassar; produk berpengaruh negatif dan tidak signifikan terhadap kepuasan pelanggan Trans Studio Makassar; promosi berpengaruh negatif dan tidak signifikan terhadap kepuasan pelanggan Trans Studio Makassar.; distribusi berpengaruh positif dan signifikan terhadap kepuasan pelanggan Trans Studio Makassar; people (orang) berpengaruh positif dan tidak signifikan terhadap kepuasan pelanggan Trans Studio Makassar; proses berpengaruh positif dan tidak signifikan terhadap kepuasan pelanggan Trans Studio Makassar dan bukti fisik berpengaruh positif dan signifikan terhadap kepuasan pelanggan Trans Studio Makassar.
\end{abstract}

Kata Kunci: Bauran Pemasaran; Kualitas Pelayanan; Kepuasan Pelanggan

\begin{abstract}
The purpose of this study was to analyze the Effect of Marketing Mix on Visitor Satisfaction at Trans Studio Makassar. The research approach used is descriptive and explanatory approaches with quantitative and qualitative methods. The research method used is multiple regression with the help of the SPSS V. 16 program, for the sample in this study were 116 customers. The results showed that: Price had a positive and significant effect on customer satisfaction in Trans Studio Makassar; the product has a negative and insignificant effect on Trans Studio Makassar customer satisfaction; promotion has a negative and insignificant effect on Trans Studio Makassar customer satisfaction; distribution has positive and significant effect on customer satisfaction of Trans Studio Makassar; people (people) positive and not significant effect on customer satisfaction Trans Studio Makassar; the process has a positive and not significant effect on Trans Studio Makassar customer satisfaction and physical evidence has a positive and significant effect on Trans Studio Makassar customer satisfaction.
\end{abstract}

Keyword: Marketing Mix; Service quality; Customer satisfaction 


\section{PENDAHULUAN}

Manusia pada hakikatnya memiliki keinginan untuk memenuhi kebutuhan hidupnya, diantaranya kebutuhan primer, sekunder dan tersier. Dalam memenuhi kebutuhan tersebut manusia harus rela bekerja agar mendapatkan penghasilan sebagai bentuk usaha dalam memenuhi kebutuhan (Annam, 2016).

Kebutuhan primer adalah kebutuhan yang benar-benar amat sangat dibutuhkan orang dan sifatnya wajib untuk dipenuhi. Contohnya adalah seperti sembilan bahan pokok atau sembako, tempat tinggal/rumah, pakaian, dan sebagainya. Kebutuhan selanjutnya adalah kebutuhan sekunder yang merupakan jenis kebutuhan lanjutan setelah semua kebutuhan pokok primer telah semuanya terpenuhi dengan baik. Kebutuhan sekunder sifatnya menunjang kebutuhan primer. seperti makanan yang bergizi, pendidikan yang baik, pakaian yang baik, perumahan yang baik, dan sebagainya yang belum masuk ke dalam kategori mewah.

Kebutuhan terakhir adalah kebutuhan tersier yakni kebutuhan manusia yang sifatnya mewah, tidak sederhana dan berlebihan yang timbul setelah terpenuhinya kebutuhan primer dan kebutuhan sekunder. Contohnya adalah mobil, smartphone, laptop,dan lain-lain. Berdasarkan penjelasan diatas kebutuhan primer dan kebutuhan sekunder dapat dipenuhi oleh manusia dengan cara bekerja sesuai dengan kemampuan dan tingkat pendidikan ataupun menciptakan lapangan pekerjaan yang ditujukan untuk mendapatkan keuntungan baik upah ataupun keuntungan yang diperoleh dapat digunakan sebagai sarana dalam pemenuhan kebutuhan. Manusia akan bekerja keras untuk memenuhi kebutuhan primer dan sekundernya. Jika kebutuhan primer dan sekunder sudah terpenuhi maka manusia akan sangat memerlukan kebutuhan tersier untuk menghilangkan kejenuhan dalam bekerja, salah satunya sarana hiburan dan bermain.

Pada saat, Indonesia sudah banyak dibangun taman hiburan atau wahana bermain keluarga, diantaranya adalah Trans Studio Makassar. Trans Studio Makassar adalah Taman bermain indoor terbesar ketiga di Dunia (tahun 2009). Bangunan ini memiliki ketinggian $20.000 \mathrm{~m} 2$. Trans Studio dibangun di area 12,7 hektare dengan investasi hingga Rp 1 triliun (sekitar Rp 104 juta USD). Taman Bermain Indoor ini diresmikan oleh Wakil Presiden Indonesia Jusuf Kalla tepatnya pada tanggal 9 September 2009. (www.wikipedia.com).

Trans Studio terletak di jalan utama dari Metro Tanjung Bunga Jalan, Makassar. Mempunyai luas 2,7 hektar ruangan dalam dan terdiri dari empat zona dengan 22 wahana yang mampu menampung 5.000 orang. Trans Studio dikembangkan di bawah manajemen PT. Trans Kalla, kemitraan antara Para Group dan Kalla Group. Chairul Tanjung adalah pendiri dan pemilik Para Group merupakan pengusaha terkaya di Indonesia. Dia memiliki perusahaan Bank Mega dan televisi penyiaran Trans Corp. Trans Corp yang mengoperasikan stasiun televisi swasta TransTv dan TV7 adalah stasiun televisi pertama yang memiliki taman dalam ruangan. Di sisi lain, Kalla Grup dimiliki oleh Jusuf Kalla, Wakil Presiden Indonesia. Bersama-sama Chairul Tanjung dan Jusuf Kalla dibuat PT. Trans Kalla pada tahun 2007. Para Group bertanggung jawab untuk pendanaan dan membangun seluruh fasilitas, sementara Kalla Group bertanggung jawab untuk menyediakan lahan. Para Group memiliki 55 persen saham dan Kalla Group memegang 45 persen. 
Pada awal proyek, taman hiburan indoor direncanakan menjadi hanya 2,4 hektar luas. Namun studi kelayakan dan survei ternyata menunjukkan pertumbuhan lebih lanjut. Manajemen Trans Kalla kemudian memutuskan untuk memperpanjang daerah dari 2,4 hektar menjadi 2,7 hektar. Dengan ukuran diperpanjang dari Trans Studio, target pelanggan juga telah meningkat $1.600 .000-2.000 .000$ selama tahun pertama. Pemerintah provinsi Sulawesi Selatan dan kotamadya Makassar mengharapkan taman bermain ini akan mampu merangsang pertumbuhan ekonomi, terutama di Makassar.

Selain proyek raksasa ini, PT. Trans Kalla mengharapkan untuk melakukan proyek serupa di Balikpapan, Bandung, dan Jakarta. Pertanyaan mengenai fakta bahwa proyek ini dibangun di Makassar, ibukota Sulawesi Selatan, bukan Jakarta, ibu kota Indonesia itu sendiri. Adapun faktor-faktor yang membuat Makassar kawasan potensi tinggi untuk daya tarik. Makassar adalah salah satu kota terbesar di Indonesia dengan populasi lebih dari satu juta orang. Terlepas dari populasi, masih banyak potensi daerah yang tinggi untuk membangun dan mengembangkan di Makassar, tidak seperti Jakarta yang penuh sesak. Selain itu, pertumbuhan ekonomi di Makassar cukup tinggi; yang 9\% produk domestik bruto (PDB) melampaui rata-rata produk nasional bruto (GNP) yang 7\%. Alasan lain adalah bahwa Sulawesi Selatan merupakan pintu gerbang utama untuk bagian timur Indonesia, yang memiliki potensi untuk prospek ekonomi selama lima sampai enam tahun ke depan.

Manajemen Trans Kalla mengharapkan dengan memilih Makassar untuk lokasi Trans Studio, mereka akan dapat mencapai dan merangkul pasar internasional. Keberadaan di daerah pariwisata, yang dekat dengan wilayah perumahan dan bisnis elit menguntungkan untuk Makassar. Pantai Selat Makassar di utara dan barat dari lokasi objek wisata yang bermanfaat lain yang akan menjadi bagian dari konsep keseluruhan pembangunan.

Menurut Zeitham dan Bitner (2004) dan Engel et al (1987) mengatakan bahwa kepuasan dan ketidak puasan merupakan dampak dari hasil penilaian pelanggan atas kualitas layanan dan nilai yang ditawarkan oleh perusahaan.

Tjiptono (2005) mengatakan bahwa kualitas layanan berpengaruh pada kepuasan pelanggan, word of mouth, pembelian ulang, loyalitas, pangsa pasar dan profitabilitas. Dari sini dapat disimpulkan bahwa pelanggan yang tidak puas akan menimbulkan perasaaan sentimentil terhadap barang/jasa yang telah dibeli serta peluang untuk melakukan pembelian ulang sangatlah kecil. Sebaliknya pelanggan yang merasakan kepuasan atas kualitas layanan yang diberikan perusahaan akan memunculkan sifat positif dan kepercayaan pelanggan terhadap barang/jasa atas perusahaan. Adanya sikap positif dan rasa kepercayaan pelanggan terhadap barang/jasa akan mendorong pelanggan untuk melakukan pembelian ulang.

Salah satu strategi yang berhubungan dengan kegiatan pemasaran perusahaan adalah bauran pemasaran strategy yang didefinisikan oleh Kotler dan Armstrong (1997) yang menyatakan bahwa bauran pemasaran as the set of controllable marketing variables that the firm bleads to produce the response it wants in the target market".

Dari definisi diatas dapat diartikan bahwa bauran pemasaran merupakan variablevariabel terkendali yang digabungkan untuk menghasilkan respon yang diharapkan dari sasaran pasar. Dan untuk usaha jasa terdapat 7 unsur bauran pemasaran (Bauran 
pemasaran-7p) yaitu: Produk, Price, Promotion, Place, Participant, Proses, Dan Physical Evidence.

Kepuasan pelanggan yang dimaksud yaitu kepuasan terhadap Product (produk), kepuasan terhadap Price (harga), kepuasan terhadap Promotion (promosi), kepuasan terhadap Place (distribusi), kepuasan terhadap participant (orang), kepuasan terhadap process (proses), dan kepuasan terhadap physical evidence (lingkungan fisik) pada Trans Studio Makassar. Hal yang terjadi sekarang adalah ada perbedaan antara harapan dan persepsi konsumen. Harapan konsumen cenderung lebih besar daripada nilai yang diterima oleh konsumen. Hal ini jika terjadi terus menerus akan membuat konsumen lari ke produk pesaing. Sehingga hal ini perlu diperhatikan secara sungguh-sungguh oleh perusahaan. 


\section{KERANGKA KONSEPTUAL}

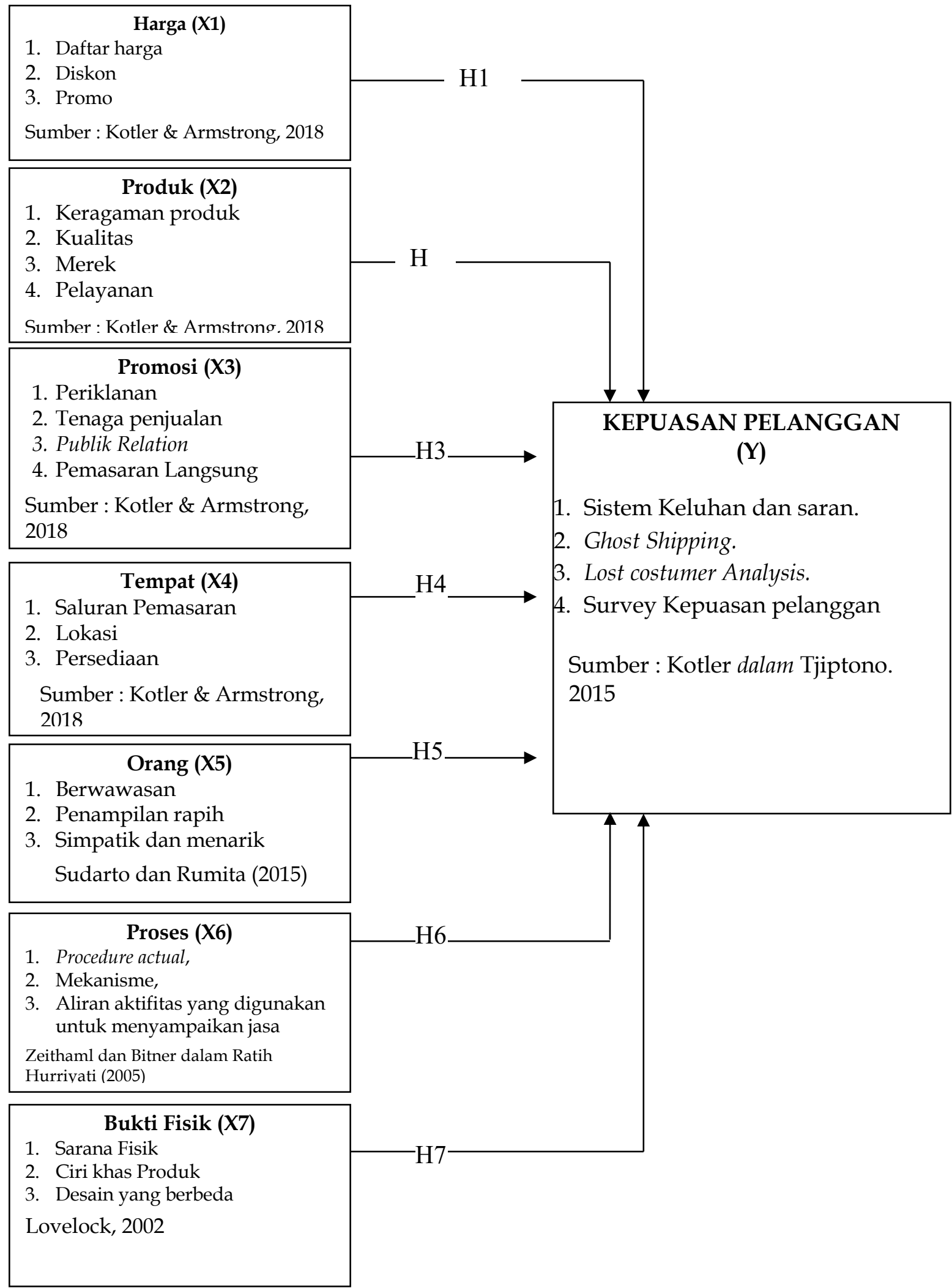




\section{METODE PENELITIAN}

Metode pengumpulan data yang digunakan dalam penelitian ini adalah observasi, kuesioner/angket, wawancara dan studi literatur.

Populasi dalam penelitian ini adalah Para Pelanggan Trans Studio Makassar / Daily Visitor. Besarnya sampel penelitian dengan jumlah pelanggan Trans Studio Makassar di wilayah Kota Makassar pada bulan Oktober 2018 akan ditentukan jumlah sampel secara keseluruhan dengan pendekatan Yamane dalam Ferdinand (2006;227) menggunakan rumus :

$$
\mathrm{n}=\frac{\mathrm{N}}{1+\mathrm{N}(\mathrm{d} 2)}
$$

Dimana :

$\mathrm{n}$ : ukuran sampel

$\mathrm{N}$ : ukuran populasi

d : presisi yang ditentukan atau presentasi kelonggaran ketidak telitian (margin of error $)=10 \%$

Maka besarnya Sampel adalah :

$$
\begin{aligned}
& \mathrm{n}=\overline{1+4854(0,1)^{2}} \\
& =97,98 \\
& \text { = } 98 \text { sampel (pembulatan) }
\end{aligned}
$$

Jadi jumlah sampel pada penelitian ini berjumlah 98 orang pelanggan pada Trans Studio Makassar.

\section{HASIL PENELITIAN DAN PEMBAHASAN}

Peneliti menggunakan uji t test untuk menguji hipotesis pertama, kedua, dan ketiga. Adapun hasil dari pengujian $t$ test sebagai berikut

\begin{tabular}{|c|c|c|c|c|c|c|}
\hline \multirow{2}{*}{\multicolumn{2}{|c|}{ Model }} & \multicolumn{2}{|c|}{ Unstandardized Coefficients } & \multirow{3}{*}{$\begin{array}{c}\text { Standardized } \\
\text { Coefficients } \\
\text { Beta }\end{array}$} & \multirow[b]{2}{*}{$\mathrm{t}$} & \multirow[b]{2}{*}{ Sig. } \\
\hline & & B & Std. Error & & & \\
\hline \multirow[t]{8}{*}{1} & (Constant) & .101 & .920 & & .110 & .913 \\
\hline & Harga (X1) & .188 & .068 & .166 & 2.771 & .007 \\
\hline & Produk (X2) & -.128 & .071 & -.149 & -1.810 & .074 \\
\hline & Promosi (X3) & -.105 & .089 & -.103 & -1.173 & .244 \\
\hline & Tempat (X4) & .396 & .137 & .273 & 2.882 & .005 \\
\hline & Orang (X5) & .175 & .190 & .137 & .920 & .360 \\
\hline & Proses $(\mathrm{X} 6)$ & .256 & .196 & .187 & 1.305 & 195 \\
\hline & Bukti Fisik (X7) & .628 & .087 & .548 & 7.209 & .000 \\
\hline
\end{tabular}

Tabel 1.

Hasil Uji Parsial dengan Uji T Test Coefficients ${ }^{a}$

a. Dependent Variable: Kepuasan Pelanggan (Y)

Sumber: Data Primer yang diolah, 2020 
Dari tabel 4.11 dapat dibuat persamaan regresi dari output tersebut yaitu:

$Y=0,101+0,188 \times 1+-0,128 X 2+0,105 X 3+-0,105 X 4+0,396$ X5 + 0,175 X6 + 0,256 $\mathrm{X} 7+0,628 \times 7$

Artinya :

Artinya:

1. Konstanta sebesar $-0,101$ tersebut bermakna apabila produk (X1), harga (X2), promo (X3) distribusi (X4), orang (X5), proses (X6), dan lingkungan fisik (X7), maka kepuasan pelanggan sebesar 0,101.

2. Nilai harga (X1) sebesar 0.188 memberi makna bahwa apabila harga (X1) bertambah 1 poin, maka kepuasan pelanggan akan meningkat sebesar 0.188.

3. Nilai produk (X2) sebesar -0.128 memberi makna bahwa apabila produk (X2) bertambah 1 poin, maka kepuasan pelanggan akan turun sebesar 0.128.

4. Nilai promosi (X3) sebesar -0.105 memberi makna bahwa apabila promosi (X3) bertambah 1 poin, maka kepuasan pelanggan akan menurun sebesar 0.105.

5. Nilai tempat (X4) sebesar 0.396 memberi makna bahwa apabila produk (X4) bertambah 1 poin, maka kepuasan pelanggan akan turun sebesar 0.396 .

6. Nilai orang (X5) sebesar 0.175 memberi makna bahwa apabila orang (X5) bertambah 1 poin, maka kepuasan pelanggan akan meningkat sebesar 0.175 .

7. Nilai proses (X6) sebesar 0.256 memberi makna bahwa apabila proses (X6) bertambah 1 poin, maka kepuasan pelanggan akan meningkat sebesar 0.256.

8. Nilai bukti fisik (X7) sebesar 0.626 memberi makna bahwa apabila bukti fisik (X7) bertambah 1 poin, maka kepuasan pelanggan akan meningkat sebesar 0.628 .

\section{Pengaruh Harga Terhadap Kepuasan Pelanggan}

Berdasarkan penjelasan Tabel 4.13 menunjukkan bahwa untuk variabel harga diperoleh nilai koefisien korelasi sebesar 0,188 dengan nilai t hitung sebesar 2,771 dan signifikansi pada 0,007 $(0,007<0,050)$, Artinya bahwa variabel harga berpengaruh positif dan signifikan terhadap kepuasan pelanggan pada Trans Studio Mall Makassar, maka hipotesis 1 dapat diterima.

\section{Pengaruh Produk Terhadap Kepuasan Pelanggan}

Berdasarkan penjelasan Tabel 4.14 menunjukkan bahwa untuk variabel produk diperoleh nilai koefisien sebesar $-0,128$ dengan nilai $t$ hitung sebesar -1,810 dan signifikansi pada 0,074 $(0,074>0,050)$, Artinya bahwa variabel produk berpengaruh negatif dan tidak signifikan kepuasan pelanggan pada Trans Studio Mall Makassar, maka hipotesis 2 dapat ditolak.

\section{Pengaruh Promosi Terhadap Kepuasan Pelanggan}

Berdasarkan penjelasan Tabel 4.14 menunjukkan bahwa untuk variabel promosi diperoleh nilai koefisien sebesar -0,105 dengan nilai $t$ hitung sebesar -1,173 dan signifikansi pada 0,244 $(0,244>0,050)$, Artinya bahwa variabel promosi berpengaruh negatif dan tidak signifikan terhadap kepuasan pelanggan pada Trans Studio Mall Makassar, maka hipotesis 3 dapat ditolak. 


\section{Pengaruh Tempat Terhadap Kepuasan Pelanggan}

Berdasarkan penjelasan Tabel 4.14 menunjukkan bahwa untuk variabel tempat diperoleh nilai koefisien sebesar 0,396 dengan nilai $t$ hitung sebesar 2,882 dan signifikansi pada 0,005 $(0,005<0,050)$, Artinya bahwa variabel tempat berpengaruh positif dan signifikan terhadap kepuasan pelanggan pada Trans Studio Mall Makassar, maka hipotesis 4 dapat diterima.

\section{Pengaruh Orang Terhadap Kepuasan Pelanggan}

Berdasarkan penjelasan Tabel 4.14 menunjukkan bahwa untuk variabel orang diperoleh nilai koefisien sebesar 0,175 dengan nilai $t$ hitung sebesar 0,920 dan signifikansi pada 0,360 $(0,360>0,050)$, Artinya bahwa variabel orang berpengaruh positif tapi tidak signifikan terhadap kepuasan pelanggan pada Trans Studio Mall Makassar, maka hipotesis 5 dapat ditolak.

\section{Pengaruh Proses Terhadap Kepuasan Pelanggan}

Berdasarkan penjelasan Tabel 4.14 menunjukkan bahwa untuk variabel proses diperoleh nilai koefisien sebesar 0,256 dengan nilai $t$ hitung sebesar 0,920 dan signifikansi pada $0,360(0,360>0,050)$, Artinya bahwa variabel proses berpengaruh positif tapi tidak signifikan terhadap kepuasan pelanggan pada Trans Studio Mall Makassar, maka hipotesis 6 dapat ditolak.

\section{Pengaruh Bukti Fisik Terhadap Kepuasan Pelanggan}

Berdasarkan penjelasan Tabel 4.14 menunjukkan bahwa untuk variabel proses diperoleh nilai koefisien sebesar 0,628 dengan nilai $t$ hitung sebesar 7,209 dan signifikansi pada 0,000 $(0,000<0,050)$, Artinya bahwa variabel bukti fisik berpengaruh positif dan signifikan terhadap kepuasan pelanggan pada Trans Studio Mall Makassar, maka hipotesis 7 dapat diterima.

Untuk pengujian secara keseluruhan, peneliti menggunakan uji $\mathrm{F}$ Test, dengan hasil uji F sebagai berikut:

Tabel 4.15.

Hasil Uji Simultan dengan Uji F Test

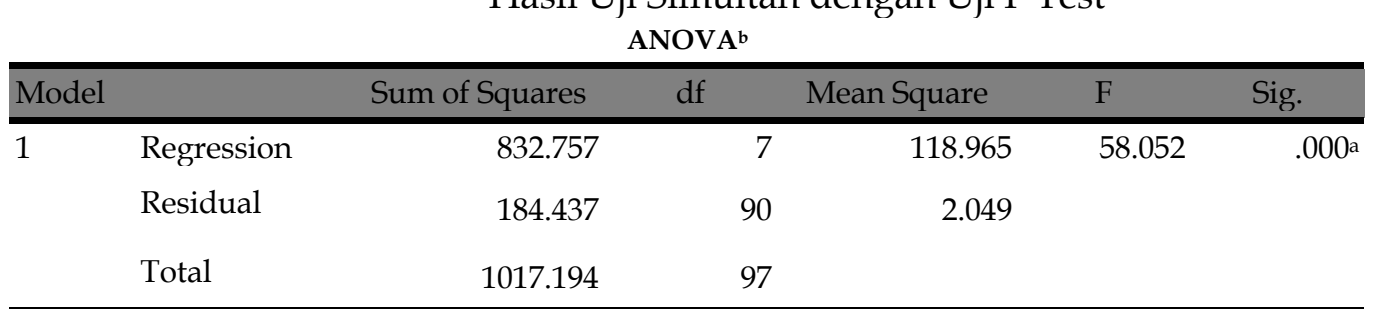

a. Predictors: (Constant), Bukti Fisik (X7), Tempat (X4), Harga (X1), Produk (X2), Promosi (X3), Proses (X6), Orang (X5)

b. Dependent Variable: Kepuasan Pelanggan (Y)

Sumber : Data Primer yang diolah, 2020

Dari tabel 4.12 diperoleh nilai $F$ hitung sebesar 118,965. Pada derajat bebas 1 $(\mathrm{df} 1)=$ jumlah variabel $-1=8-1=7$, dan derajat bebas $2(\mathrm{df} 2)=\mathrm{n}-\mathrm{k}=97-7=90$, dimana $\mathrm{n}=$ jumlah sampel, $\mathrm{k}=$ jumlah variabel, nilai $\mathrm{F}$ tabel pada taraf kepercayaan signifikansi 0,050 adalah 2,84; dengan demikian F hitung $>\mathrm{F}$ tabel yaitu 58,052 > 2,11 pada tingkat signifikansi $0,000(0,000<0,050)$. Karena probabilitas signifikansi jauh 
lebih kecil dari sig < 0,05, maka model dikatakan, bahwa Harga (X1), Produk (X2), Promosi (X3), Tempat (X4), Orang (X5), Proses (X6), dan Bukti Fisik (X7) secara bersama-sama (simultan) berpengaruh positif dan signifikan terhadap kepuasan pelanggan pada Trans Studio Mall Makassar. selanjutnya hasil uji koefisien determinasi dalam penelitian ini dapat dilihat pada tabel 4.16 berikut ini:

Tabel 4.16

Uji Koefisien Determinasi

Model Summary

\begin{tabular}{lrrrrr}
\hline Model & $\mathrm{R}$ & & R Square & Adjusted R Square & Std. Error of the Estimate \\
\hline 1 & & $.905^{\mathrm{a}}$ & .819 & .805 & 1.432 \\
\hline
\end{tabular}

a. Predictors: (Constant), Bukti Fisik (X7), Tempat (X4), Harga (X1), Produk (X2), Promosi (X3), Proses (X6), Orang (X5)

Sumber : Data Primer yang diolah, 2020

Dari tabel 4.16 diperoleh nilai $\mathrm{R}$ square sebesar 0,819 memiliki arti bahwa kemampuan variabel bebas yang terdiri dari Harga (X1), Produk (X2), Promosi (X3), Tempat (X4), Orang (X5), Proses (X6), dan Bukti Fisik (X7) untuk menjelaskan besarnya variasi dalam variabel terikat yaitu kepuasan pelanggan sebesar 0,819 atau $81,9 \%$ sedangkan sisanya $19,1 \%$ dijelaskan variabel lain yang tidak masuk dalam persamaan yang diteliti.

\section{KESIMPULAN}

Dari hasil analisis data dan pembahasan yang telah dikemukakan maka dapat disimpulkan beberapa hal sebagai berikut:

1. Harga berpengaruh positif dan signifikan terhadap kepuasan pelanggan Trans Studio Makassar.

2. Produk berpengaruh negatif dan tidak signifikan terhadap kepuasan pelanggan Trans Studio Makassar.

3. Promosi berpengaruh negatif dan tidak signifikan terhadap kepuasan pelanggan Trans Studio Makassar.

4. Distribusi berpengaruh positif dan signifikan terhadap kepuasan pelanggan Trans Studio Makassar.

5. People (orang) berpengaruh positif dan tidak signifikan terhadap kepuasan pelanggan Trans Studio Makassar.

6. Proses berpengaruh positif dan tidak signifikan terhadap kepuasan pelanggan Trans Studio Makassar.

7. Lingkungan fisik berpengaruh positif dan signifikan terhadap kepuasan pelanggan Trans Studio Makassar.

\section{SARAN}

1. Agar pihak manajemen Trans Studio Mall (TSM) mempertahankan Harga yang saat ini berlaku sehingga kepuasan pelanggan tetap terjaga.

2. Agar pihak manajemen Trans Studio Mall (TSM) memperbaiki kualitas produk yang ditawarkan kepada pelanggan sehingga sesuai harapan.dan memperbaharui produkproduk yang ditawarkan. 
3. Agar pihak manajemen Trans Studio Mall (TSM) lebih memperhatikan promosi yang dibuat dan sesuai dengan segmennya.

4. Agar pihak manajemen Trans Studio Mall (TSM) mempertahankan distribusinya terutama pada saluran pemasarannya.

5. Agar pihak manajemen Trans Studio Mall (TSM) lebih memfokuskan pada perekrutan karyawan agar mendapatkan SDM berkualitas sehingga dapat memberikan pelayanan yang maksimal kepada pelanggan.

6. Agar pihak manajemen Trans Studio Mall (TSM) meningkatkan proses pemberian pelayanan kepada pelanggan sehingga pelanggan memperoleh pelayanan yang maksimal.

7. Agar pihak manajemen Trans Studio Mall (TSM) memberikan pelatihan berkala kepada karyawannya untuk menambah Product Knowledege sehingga mampu beradaptasi setiap terjadi perbahan.

\section{DAFTAR PUSTAKA}

Annam, R. (2016). Hakikat Ekonomi Islam Tentang Kelangkaan Sumber Daya Ekonomi Dan Kebutuhan Manusia (Era Globalissasi Dan Industrialisasi). AlMasharif: Jurnal Ilmu Ekonomi Dan Keislaman, 4(1), 127-144.

Engel, James F., Blackwell, Roger D \& Miniard, Paul W, (2002), Prilaku Konsumen, Prenhallindo, Jakarta.

Kotler, Philip and Gary Amstrong, (2004), Principles of Marketing, Pretice Hall Inc., (10 ${ }^{\text {thed, }}$ ) Englewood Cliffs, New Jersey

Sudarto, A., \& Rumita, R. (2015). Analisis Pengaruh Bauran Pemasaran 7p terhadap Keputusan Pembelian Konsumen (Studi Kasus PT. Pos Indonesia Kpc Surabaya Selatan). Industrial Engineering Online Journal, 4(1).

Tjiptono, Fandi, (2001) Strategi Pemasaran. Edisi 1, Andi Offset, Yogyakarta.

Zeithaml, Valarie A., A. Parasuraman, and Leonard L. Berry, (1990), Delivering Quality Service: Balancing Customer Perceptions and Expectation, The Free Press, New York 